MAGR

GOVS

MN 2000 EP- no.124

JNIVERSITY OF MINNESOTA

$!$

AGRICULTURAL EXTENTION SERVICE

a.

PANPHITT 124

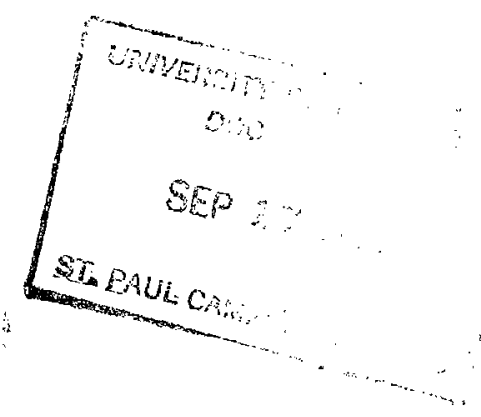

VEGETABLË DISRASES AND THEIR COLTROL 
This archival publication may not reflect current scientific knowledge or recommendations Current information available from University of Minnesota Extension: http://www. extension.umn.edu 


\section{4}

\section{Vegetable Diseases and Their Control}

CARL J. EIDE-R. C. ROSE

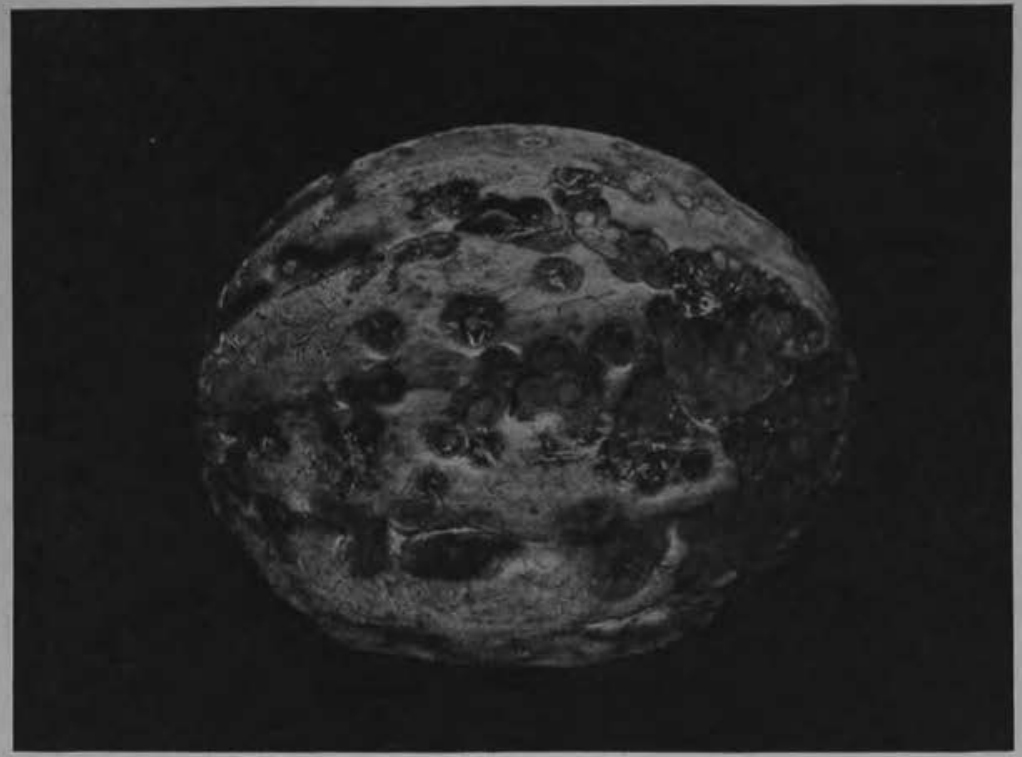

Muskmelon affected with anthracnose disease which destroys both fruit and vine.

U N I VE R I T Y OF M IN N ES O T A
griculture Extension Service U. S. DEPART MENT OF A GRICULTURE 


\title{
Vegetable Diseases and Their Control
}

\author{
Carl J. Eide and R. C. Rose
}

$P$ LAN'T disease control is largely prevention, and to be effective must be started before the disease becomes established. Often the control measures must be applied before the seed is planted; sometimes even earlier.

\section{ASPARAGUS}

Rust-Rust is the only disease that ever damages asparagus much in Minnesota, and, since rust-resistant varieties have become general, the disease has become rare. On susceptible varieties, the typical red rust pustules may develop abundantly on all the above-ground parts of older plants and reduce the yield of sprouts the next season.

As the rust fungus overwinters on the old stalks, careful collection and burning of old stalks in the fall will tend to reduce the amount of rust. During the cutting season all shoots should be cut to prevent their infection by overwintering spores. The best control, however, is to grow the more resistant varieties such as the Mary or Martha Washington.

\section{BEANS}

Anthracnose-Anthracnose or pod spot is a common disease of beans but is destructive only in seasons with abundant rainfall. Brown sunken spots with pink sticky masses of spores may be seen on the pods. The fungus lives from year to year in infected seed.

To prevent anthracnose, buy new seed each year, preferably that grown in dry regions of Idaho, Colorado, and other western states. Because the anthracnose fungus may survive on the dead stalks and crop refuse, avoid growing beans on the same soil two years in succession. If beans are cultivated or picked while the plants are wet, the disease will be spread.

Bacterial Blight-Several bacterial diseases of beans are prevalent in Minnesota every year and often do great damage. All cause spotting and dying of the leaves and blemishing of the pods. On affected pods, the spots are sometimes confused with anthracnose. The spots caused by the bacterial blights are not sunken as with anthracnose and they are less regular in outline. A yellow or translucent area is often present about the water-soaked blotches caused by the bacterial diseases. The bacteria causing these diseases are carried in infected seed.

The only practical control is planting disease-free seed, particularly that from arid areas of the west. Picking and cultivation should be avoided when the plants are wet.

Mosaic-Mosaic, a common and often destructive disease of beans in Minnesota, causes small stunted plants with pale green, mottled leaves and very little fruit. The virus is spread by plant lice and is also seed-transmitted.

Several varieties of beans now available are immune or tolerant to common mosaic. Some of these are also somewhat resistant to bacterial blight. See pages 5-6 for diseaseresistant varieties.

Rust-Rust, though often present on beans in Minnesota, is rarely very destructive. Brown rust pustules are found on leaves, stems, and pods and may reduce the yield of marketable pods. The rust fungus overwinters on the dead plants, and control depends on the effective collection and burning of all old plants in the fall and on crop rotation.

\section{CABBAGE}

Black rot-Black rot is one of the most common diseases of cabbage in Minnesota. The bacteria are carried in the seed and may also overwinter in the soil. Plants affected with black rot are stunted, and the leaves turn yellow and fall off. Badly affected plants may be killed in the seedling stage. Some lightly affected plants may survive, but they will rarely form marketable heads. The heads that are produced have blackened veins in the stump and are likely to rot in storage.

The hot water treatment (see table 1) is the most effectlve for black rot control, but may reduce germination. If it is used, a germination test should be made after treatment. Mercuric chloride treatment for 30 minutes is fairly effective. Seed from the Puget Sound region is usually free of blackleg and need not be treated except for damping-off. Seed treatments containing copper should not be used on cabbage. Since bacteria may survive in the seedbed soil, it is advisable to use clean soil, or to sterilize the seedbed soil before it is used.

Under moist conditions black rot will spread rapidly from plant to plant in the 
seedbed, although the symptoms will not appear until the plants are set out in the field. It is, therefore, advisable to give the plants as much ventilation as possible in the seedbed, so that drops of moisture will not stand on the plants.

Yellows or Cabbage Wilt-Yellows, or cabbage wilt, became very prevalent in Minnesota during the hot, dry summers of 1935, 1936, and 1937. The disease, often confused with black rot, is caused by a fungus that lives from year to year in the soil. It usually is not transmitted in the seed. Plants affected with yellows are stunted, the leaves turn yellow and drop off, and the plants often die before a head is formed. Sometimes small and poorly developed heads are formed. The only control is to grow the yellowsresistant varieties. A half dozen or more varieties including early, midseason, and late types are available from most seed dealers and are usually designated in catalogs as yellows-resistant. (See also the section on disease-resistant varieties.) These varieties will give a good crop on infected soil where the old varieties will be a complete failure. Where yellows has once appeared only the resistant varieties should be grown.

Blackleg-Blackleg is caused by a seedborne fungus that may also overwinter in the seedbed. It is quite common in the cool, lake regions of northeastern Minnesota. The fungus attacks the roots and the lower parts of the stem, causing a dry rot and may also cause spotting of the leaves. Seed treatment and the use of clean soil in the seedbeds as recommended for the control of cabbage black rot are advised. Destroy old cabbage refuse on nearby fields to avoid infection from old leaves blown over new plantings. Ample ventilation of the beds is also recommended.

Clubroot-Clubroot, rapidly becoming established in Minnesota, is caused by a fungus that lives from year to year in the soil, and is often found in low, poorly drained places. It causes large swellings on the roots, resulting in stunted growth and small, worthless heads. Affected roots are often decayed by a bacterial rot in midseason, killing the plant. It is spread by cultivating tools or on the feet of animals and may be introduced into new localities by planting infected seedlings.

For this reason, it is recommended that, if possible, a grower should produce his own plants from seed. Infected seedlings cannot always be detected. If any root swellings indicating clubroot are found in a lot of seedlings, it would be best to discard the whole lot.

Where clubroot has become established, losses may be reduced by applying hydrated lime to the infected soil at the rate of 25 pounds per square rod, and by rotating crops so as to avoid growing cabbage or other cruciferous crops on the affected soil for several years.

\section{CELERY}

Late Blight-Late blight is the most common and destructive disease of celery in $\mathrm{Min}$ nesota. The fungus is often carried in and on the seed and also commonly survives in the remains of celery plants in the field and seedbed.

The disease is favored by rainy or humid weather but may be destructive in dry weather if water is applied frequently. It can be controlled effectively by spraying or dusting with a copper fungicide. (See the section on sprays and dusts.) . Two or three applications must be made in the seedbed while the plants are verx small, followed by four or five after transplanting.

Yellows-Yellows is a fungus disease. It stunts the plants and causes them to turn yellow early in the season. Often the crown will be rotted inside with a brick-red decay. The fungus lives in the soil, and once the soil is infested it is always "celery sick."

The use of resistant varieties is the only way to produce satisfactory crops on "celery sick" soil. (See list of resistant varieties.) Growers who do not have yellows in their fields should never buy plants as this is the principal way that the disease is spread from field to field. Such growers, by raising their own plants, will prevent or delay the appearance of the disease and enable them to continue raising varieties that are not resistant.

\section{CUCURBITS (CUCUMBERS. MUSKMELONS, SQUASH, ETC.)}

Mosaic-Mosaic of cucurbits, the most destructive disease of cucumbers, also occurs on other cucurbits and affects many weeds. The virus is rarely seed-transmitted, but commonly survives the winter in the roots of infected perennial weeds such as milkweed and wild cucumber. In the spring insects spread it from the new growth on weeds to the young cucurbits. It stunts the plants, and gives the leaves a mottled appearance, with light and dark green areas, especially noticeable at the tips of the new growth. Older leaves may turn brown and dry up. The fruits are often small and distorted.

The disease is difficult to control. Where cucurbits are grown intensively, the perennial weeds become infected and the disease 
is very prevalent. Cucurbits grown in isolated places are seldom affected. The eradication of all perennial weeds such as milkweed and nightshade, as well as the annual wild cucumber in the vicinity of cucumber fields, is said to give good results. Shamrock, a recently introduced variety of slicing cucumber, is sald to be resistant to mosalc. It is satisfactory for home gardens, but is not favored by commercial plckle companies.

Bacterial wut-Bacterial wilt, common on cucurbits in Minnesota, causes a slow wilting of the plants. The bacteria live in the waterconducting vessels of the stem and cut off its water supply. They enter the plant through the feeding wounds made by cucumber beetles. The beetles constitute the only known means of spreading the disease. The bacteria also survive the winter in the bodies of the overwintering insects. For these reasons, the only control of the disease lies in the control of the cucumber beetle. See page 23.

Anthracnose-Anthracnose is common on melons in wet years or when overhead Irrigation is used excessively. The fungus forms small spots on the leaf veins and larger, brown sunken spots with pink centers on the fruit.

Where the disease is present, it is advisable to avoid overhead Irrigation and to spray the plants at frequent intervals with one of the "fixed copper" sprays or dusts (tribasic copper sulphate or copper oxide) plus an insecticide for insect control. Bordeaux mixture is likely to injure most cucurbits, but may be used in the latter part of the season on watermelons. As the fungus spores are often carried on the seed, seed should be disinfected with a mercuric chloride solution. See table 4 for directions. Crop rotation will also help to reduce the disease. If the same field is planted to melons two years in succession, or if melon fields in successive years are near by, all old trash should be removed and burned in the fall or early spring.

Muskmelon Wut-Muskmelon wilt is a destructive fungus disease, known only in a few areas. It was first observed in 1931 in Hennepin county, where a loss as high as 90 per cent was caused in several large fields. Observations since 1931 show that it is slowly spreading.

The fungus lives indefinitely in the soll and may kill muskmelon plants at any stage of growth. Affected plants wilt and die within a few days, and often have long brown streaks along the stem in the early stages. The disease affects muskmelons only. It may be introduced into new fields by infected dirt adhering to tools or the feet of animals, or it may be introduced on seed from infected fruits. Seed should be treated as recommended for anthracnose. Wilt-resistant varieties have been developed and are being tested for quality. One of these resistant varieties, named the "Golden Gopher," has been introduced recently by the Minnesota Agricultural Experiment Station.

Watermelon wilt has been increasingly common in Minnesota in the past few years. Although this disease and the muskmelon wilt are caused by similar fungl, either disease may be present in the soil without the other, or both diseases may be present. Watermelon wilt can be controlled only by the use of resistant varieties of which there are a number available. (See list on pages 5-6.)

\section{PEAS}

Root Rot-Root rot is the most common disease of garden peas. It is caused by several different fungl that live in the soll. The fungl attack the roots most readily when the soil is excessively wet. Continued growth of peas on the same soil favors root-rot development. Rotation of crops and the planting of peas in the better-drained soils will help control these diseases, while seed treatment with Semesan or Spergon seems to be beneficlal in some cases.

Wilt-Wilt of peas, common in Minnesota, resembles root rot in some respects, but is caused by different fungi. Infected plants die prematurely. Some varieties of peas are more resistant to wilt than others, and where wilt is present in the soil much loss may be prevented by growing the more resistant varieties.

\section{SWEET CORN}

Seedling Blight-Seedling blight of sweet corn is caused by several different fungl that commonly live in the soll, but may also be carrled in infected seed. These fungi ordinarily injure the seedling only when it is growing in soll that is too wet and cold.

Experiments have shown that dusting the seed with an organic mercury dust, such as Semesan Jr., will protect the seed during the critical period and greatly increase the stands in unfavorable weather. The cost of the treatment is small, and all sweet-corn seed should be dusted before planting.

Smut-Smut, a very destructive disease of sweet corn, is diffcult to control. In gardens where corn is grown year after year on approximately the same ground, the disease may be reduced by burning all old stalks and refuse. This should be done as soon as possible after the crop is harvested before the smut has been shaken from the 
stalks. Barnyard manure from farms where corn is fed is likely to contain a lot of smut, and it is desirable to avold the use of such manure.

A new variety produced by the Minnesota Agricultural Experiment Station, known as Minhybrid 202, is more resistant than older. open-pollinated varieties.

\section{TOMATOES}

Blossom-end Rot-Blossom-end rot is one of the most common diseases of tomatoes in Minnesota. The fruit decays at the blossom end or point. The disease is caused by excessive transpiration or loss of water following abrupt changes from moist to dry weather. It is worse in light soils of poor water-holding capacity, or in clay solls that tend to bake, and is induced by excessive fertilization with nitrogen. In dry seasons, the periodic applications of water, permitting wide fluctuations in the water supply, greatly increase blossom-end rot. Good cultivation and the maintenance of a unlform soll moisture are the only practical control measures.

It has been reported that spraying with Bordeaux mixture increases blossom-end rot, and this is one of the reasons for avoiding this type of copper spray.

Leaf Spot-Leaf spot, also known as Septoria leaf spot and "blight," is destructive in Minnesota during wet seasons. The spots, 1/16 to 1/8 Inch in diameter with grey centers, appear flrst on the lower leaves. The affected leaves turn yellow, dry, and fall off. Spotting and falling of the leaves progresses from the bottom of the plant upwards, practically defoliating the plants in wet seasons. Fruits on such plants may turn red after the leaves are gone, but wlll be of poor quality.

Spraying or dusting with one of the "fixed coppers" is the best control for Septoria leaf spot. Spraying should be started when the first spots appear on the lower leaves, and the foliage should be kept covered untll the crop is nearly mature. (See discussion of sprays.) Rotation and destruction of old tomato vines and refuse will also help to reduce the disease early in the season.

Mosalc-Mosaic, common on tomatoes, causes a mottled and light green color of the leaves and often stunts the plants and reduces the yield. It may be spread by sucking insects and also by man while cultivating or pruning the plants. It may affect many other plants, including wild perennial weeds. It is thought to overwinter in the roots of such plants. Eradication of all perennial weeds in the vicinity of tomato flelds and seedbeds is recommended. The early recognition of the disease and the removal of affected plants will often prevent its spread.

\section{DISEASE-RESISTANT VARIETIES}

Many varieties of vegetables which are resistant to specific diseases are now on the market. When a variety is labeled "disease-resistant" in a seed catalog it generally means that the variety is resistant to one disease but susceptible to others. Some seed companies state definitely to what diseases a given variety is resistant, while others may be vague.

The degree of disease resistance is variable in most cases; some varieties may contract a disease but still produce a fair crop. These are usually called "disease-tolerant." In others a few individual plants may become affected with the disease to which the variety is supposedly resistant, while still other varieties break down entirely after a few years, or under unusual soil or climatic conditions. Consequently, although the use of resistant varieties is probably the best, and in some cases, the only method of disease control, perfect results are not always assured by the phrase "disease-resistant."

Here is a list of the common diseaseresistant varieties of vegetables:

ASPARAGUS-Resistant to rust-Mary and Martha Washington.

BEANS (Dry)-Immune to common mosaic-Michigan Robust, Idaho Great Northern, Michelite.

BEANS (Late garden and canning)-Immune to common mosaic and highly resistant to bacterial blight-Idaho Refugee, Sensation Refugee 1066, Sensation Refugee 1071, U. S. No. 5 Refugee, Wisconsin Refugee.

BEANS (Midseason garden and canning)Tolerant to common mosaic and bacterial blight-Giant Stringless, Tendergreen, Asgrow Stringless, Improved Kidney Wax, Round Pod Kidney Wax.

CABBAGE-Resistant to cabbage yellows-Jersey Queen (55 days), Resistant Detroit (55 days), Racine Market (60 days). Marion Market (70 days), Globe (75 days), Wisconsin Ballhead (85 days), Red Hollander 
(100 days), Wisconsin All Seasons (90 days), Wisconsin Hollander (100 days), Bugner (110 days). Many other varieties are available.

CELERY-Resistant to celery yellowsMichigan Golden (self-blanching); Paragon, Earligreen, Sweetheart (green). Most green varieties are resistant, although there are some susceptible ones.

PEAS-Resistant to fusarium wilt-Dwarf Alderman, Teton, Asgrow 40, Telephone (for home and market garden and freezing). Resistant strains of many varieties, including a large number for canning, can be obtained.

POTATO-Resistant to common scab-Burbank Russet, Russet Rural (late varieties). Resistant to late blight-Sebago (late variety).

MUSKMELON-Resistant to fusarium wilt-Golden Gopher.

WATERMELON-Resistant to fusarium wilt-Kleckley No. 6, Leesburg, Improved Stone Mountain No. 5.

HEAD LETTUCE - The variety Cos escapes lettuce drop because of its erect habit of growth.

\section{DAMPING-OFF}

Damping-off is a disease of seedlings of vegetables and flowers. The seedlings rot and turn moist at the soil surface, then topple over and die. Sometimes the seedlings are killed before they emerge from the soil. When this occurs the average gardener blames the seed, although such seed may germinate well.

Damping-off is caused by fungi in the soil and on the seed. The disease is worse under warm, humid conditions and when the seedlings are crowded and the light and ventilation are poor.

The following procedures will help reduce damping-off:

For growing seedlings, if possible use soil that has not grown vegetables or flowers for some time.

Soil consisting of about half sand is less conducive to damping-off than soil high in organic matter.

Small amounts of soil can be partially sterilized in the cook-stove oven. Place the soil in pans about 2 inches deep and put a small potato in the soil. Bake until the potato is thoroughly cooked and the soil will be free of most fungi.

Treat the seed according to the directions given under Seed Treatment.

Do not plant the seed too thick. The farther apart the seedlings are the faster they dry off.

Keep the flats or pots in a welllighted, well-ventilated place.

Do not water too heavily nor too often.

Red copper oxide can be used as a spray on seedlings of plants not sensitive to copper. Directions are given on the container.

For seed planted directly in the garden, seed treatment, good drainage, and avoidance of over-watering are the best control measures. The copper oxide spray helps some seedlings but must be used with caution.

\section{SEED TREATMENT}

Treatment of garden seeds with chemicals or hot water helps control certain diseases, mostly damping-off. Not all seeds are sufficiently benefited to justify the trouble. The crops that generally are helped by seed treatment are shown in table 1.

The hot water treatment usually reduces germination and unless great care is used, much of the seed may be killed. An accurate thermometer should be used and the water kept at exactly $122^{\circ} \mathrm{F}$. during the treatment. The seed is placed in a loose cheesecloth bag, not over half full so the seed can move freely, and dipped in water at $110^{\circ} \mathrm{F}$. for a few minutes to warm the seed. The bag containing the seed is then placed in the water at $122^{\circ} \mathrm{F}$. for exactly 25 minutes, and then plunged into cold water. The seed is then dried in a warm, dry location protected from sun. An electric fan is helpful in drying. To test the effect of the treatment, a small lot of seed can be treated first and a germination test run to de- 
Table 1. Seed Treatments Recommended for the Control of Diseases of Garden Vegetables

\begin{tabular}{|c|c|c|}
\hline Seed & Recommended materials and procedure & $\begin{array}{l}\text { Diseases } \\
\text { Controlled }\end{array}$ \\
\hline Lima bean & Spergon - $1 / 2$ tsp. to $1 \mathrm{lb}$. of seed & Damping-off \\
\hline Beet & Red copper oxide-1 oz. (5 tsp.) to $4 \mathrm{lb}$. of seed & Damping-off \\
\hline $\begin{array}{c}\text { Cabbage and } \\
\text { cauliflower }\end{array}$ & $\begin{array}{l}\text { Hot water, } 122^{\circ} \mathrm{F} \text {. for } 25 \text { min. } \dagger \text { or mercuric chloride, I } \\
\text { tablet per pint of water (a } 1-1000 \text { solution). Soak seed } \\
30 \text { min., wash thoroughly and dry } \\
\text { Follow with Semesan-1/2 tsp. per lb. of seed }\end{array}$ & $\begin{array}{l}\text { Black rot and } \\
\text { blackleg } \\
\text { Damping-off }\end{array}$ \\
\hline Corn & Semesan $\mathrm{Jr} .-1 / 4$ tsp. per $1 \mathrm{~b}$. or $11 / 2$ oz. per bushel & Seedling blight \\
\hline Lettuce & Red copper oxide-11,2 tsp. per lb. & Damping-off \\
\hline $\begin{array}{l}\text { Muskmelon and } \\
\text { watermelon }\end{array}$ & $\begin{array}{l}\text { Mercuric chloride, } 1 \text { tablet per pint of water }(1-1000) \text {. } \\
\text { Soak seed } 5 \text { min., wash thoroughly and dry. } \\
\text { Follow with red copper oxide-1/5 tsp. per lb. of seed }\end{array}$ & $\begin{array}{l}\text { Anthracnose } \\
\text { Damping-off }\end{array}$ \\
\hline Peas & 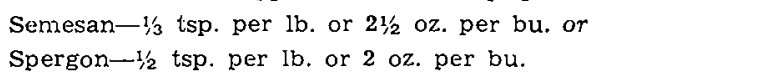 & $\begin{array}{l}\text { Damping-off } \\
\text { Damping-off }\end{array}$ \\
\hline Spinach & $\begin{array}{l}\text { Red copper oxide-11/2 tsp. per lb. or Zinc oxide }-4 \text { tsp. } \\
\text { per lb. }\end{array}$ & Damping-off \\
\hline
\end{tabular}

* Spergon is a new treatment. If not available locally, write to the University Farm, St. Paul, Minnesota, for names of dealers.

$\dagger$ See discussion of seed treatment for further directions on the hot water treatment.

termine the extent of injury. Seed lots vary a great deal in their resistance to the hot water treatment.

The rate of application of the dusts in table 4 is given in level teaspoons per pound of seed. This is more seed than most gardeners will use, but it is difficult to find a common unit of measure for the dusts small enough to use on the ordinary small packets of seed. The best thing to do in such cases is to put a quantity of dust about the size of a match head in the packet of seed and shake it vigorously. If the seed is then shaken in a fine screen or rolled around on a piece of rough paper to remove excess dust, it is probable that there will be no seed injury. The dust should appear as a fine, uniform coating on the treated seed.

Seed treated with the mercuric chloride soak should not be kept in the solution longer than recommended. The seeds should be washed thoroughly in clean water immediately after treating and spread out to dry before planting. Mercuric chloride (corrosive sublimate) is a deadly poison and is usually sold as blue tablets. These vary in size.
Ask your druggist how many to add to a pint of water to make a $1-1000$ solution.

\section{SPRAYS AND DUSTS}

Of the vegetable crops grown by the average gardener, the only ones that require sprays or dusts for disease control are tomatoes, potatoes, vine crops (cucurbits), and celery. Occasionally carrots need a fungicide to prevent leaf spot. Directions for spraying or dusting to control specific diseases are given with the discussion of these diseases, and the following information is of a general nature only.

All of the vegetables mentioned above require copper fungicides; sulphur is generally ineffective in controlling the diseases concerned.

There are now a number of copper sprays and dusts available. Of these Bordeaux mixture and copper-lime dust are the oldest and perhaps the most effective. For the average gardener they have two disadvantages: they are more trouble to use than the newer fungicides, and they contain 
lime, which is injurious to most vine crops and, under some conditions, to tomatoes.

The so-called "fixed coppers" are the easiest to use and the least likely to injure the crops. There are several types of these consisting principally of tribasic copper sulphate, red or yellow copper oxide, and several other copper compounds. These come in concentrated form to use as sprays, or diluted with inert materials to use as dusts. Most dealers will have one or more of these materials. Many of the dusts come mixed with insecticides.

The small gardener will find it most convenient to use dusts, although they are generally less effective than sprays. Small hand dusters and sprayers are inexpensive, but may be difficult to $o b$ tain now. If none are available, dust can be applied from a strong, finemeshed bag. A flour sack after a couple of washings or an old potato sack is good. The dust is put into the sack and shaken over the plants or held beside the plants and struck with a stick. This is slow and wasteful of dust, but will work in small gardens.

Dusts and spraying should be applied when the air is still. Dusts stick best to wet plants so early morning is the ideal time.

Remember that dusts and sprays are preventive measures and should be put on before a disease appears. Following directions closely for each disease and careful coverage of all susceptible plant surfaces are most essential in successful disease control.

Material contained in this pamphlet is taken from Extension Bulletin 174, "Vegetable Gardening," revised edition, March, 1943.

\section{UNIVERSITY FARM, ST. PAUL, MINNESOTA}

Cooperative Extension Work in Agriculture and Home Economics, University of Minnesota, Agricultural Extension Division and United States Department of Agriculture Cooperating, Paul E. Miller, Director. Published in furtherance of Agricultural Extension Acts of May 8 and June $30,1914$. 20M-5-43 
UWIVERSITY OF MIINESOTA

AGRTOLTUEAL ERERTIET T STATION 
UNIVERSITY OF MINNESOTA

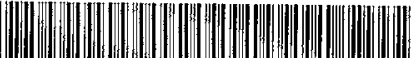

31951 D02 961967 B 